\title{
CRÔNICA UNIVERSITÁRIA
}

\section{ORAÇÃO DE PARANINFO}

RENÉ ARIEL DOTTI

Professor de Direito Penal da Faculdade de Direito da Universidade Federal do Paraná.

Aqui mesmo, há treze anos, recebia eu também o grau de $\mathrm{Ba}$. charel em Direito. Lembro bem a emoção e a ansiedade que visitavam meu espírito naquela noire de alegrias e compromisso, como a noite de hoje.

No itinerário de minha existência, aqueles momentos marcavam um ponto de partida para consolidar a opção de vida profissional. Mas não traduziam somente a eleição de atividade futura em termos de sobrevivência material; significavam, e muito, a definição de meu comportamento na sociedade, comprometido com enormes dúvidas sobre a condição do Homem em sua natureza e em seus fins.

A minha experiência, que não fora plasmada por símbolos fátuos e doutrinas herméticas, sempre liberiava meu espírito às deambulações frequentes para buscar a importância do meu ser e os valores de minha circunstância.

Quantas vezes, em quantas noites durante o tempo de vivência universitária eu me perguntava sobre as questões de amor, de paz e de liberdade ao meio de indagações das ensinanças jurídicas que também ocupavam minhas atenções.

O meu repertório de inquietações foi refinado com os estágios dedicados ao featro, ao jornalismo e a crônica literária do coditiano que abriram outras perspectivas de sensibilidade, envolvendo-me ainda mais no intenso processo da existência.

Estava eu, assim, preocupado com a essência e a forma dos homens e das coisas; com a procura da verdade sobre a vida e o mundo; com a escolha da filosofia e da religião que disciplinassem as minhas incertezas e também com a maior responsabilidade que era a síntese de todas as apreensões: a descoberta de mim mesmo.

(*) Discurso proferido em 1.0 de março de 1972, na Reitoria da Universidade. 
Foi com esse estado de alma que recebi o grau de Bacharel, na dúvida se os instrumentos conferidos pelo Direlto poderiam satisfazer as cogitações do conhecimento e harmonizar minhas tendências, dirigindo-as numa atividade que me permitisse viver com dignidade e convicção.

Iniciei, então, a jornada na advocacia procurando estímulo constante na biografia daqueles que tanto enobreceram a profissão e no exemplo de muitos outros que diariamente venciam os mesmos caminhos na defesa dos interesses que lhes eram confiados.

Em mim habitavam personagens mortas e vivas recebendo força, inspiração, conselho e comunicação.

Anos mais tarde, pelas mãos carinhosas de ILDEFONSO MARQUES, o meu grande Mestre, fui conduzido a Faculdade de Direito para iniciar uma nova experiência: transmitir lições de Direito Penal.

Assim, hoje estou, como Advogado e Professor, consciente de meus encargos e sabedor de minhas limitações.

Se eu tivesse de recomeçar a vida, faria tudo outra vez, com a mesma emoção e a mesma expectativa que experimentei há treze anos.

A homenagem que recebo desta notável turma, distinguindo-me como seu Paraninfo, constitui minha realização humana no ciclo do magistério.

Considero ainda mais essa honraria porque fui lembrado, no rol dos homenageados, ao lado de ERNANI GUARITA CARTAXO, diligente e carinhoso Mestre de várias gerações; de ATHOS MORAES DE CASTRO VELLOZO, figura modelar de lealdade e um sacerdote do humanismo; de LAMARTINE CORREA DE OLIVEIRA LYRA, exemplo de integração nos deveres do magisịério; de EGAS DIRCEU MONIZ DE ARAGÃO, o administrador vibrante e impulsor dos jovens professores ainda hesitantes quanto à sua fixação na carreira docente; de IVAN ORDINI RIGHI, o talentoso orientador de Direito Processual Civil e brilhante Promotor de Justiça, e de Sua Magnificência, o Doutor ALGACYR MUNHOZ MÄDER, Reitor da Universidade Federal do Paraná, homem de diálogo aberto e Professor dos professores de Direito que não esqueceram suas lições de matemática quando das andanças colegiais.

Na passagem de tres anos de convívio universitário, recebi sempre dos colegas mais jovens e agora Bacharéis, as maiores atenções pessoais e pude constatar a dedicação pelas tarefas que thes eram 
atribuidas, numa definição de responsabilidade que tanto aproxima Mestre e discípulos.

Não tenho a pretensão de julgar que aprendestes tudo quanto fosse necessário para melhor conhecer a ciência do Direito Penal, posto que existe ainda um longo caminho a percorrer, no qual as inquietações apenas serão atenuadas pelo exercício da pesquisa e pela maior integração nos estudos.

Todos vimos, junios, que o Direito Penal dos tempos modernos reclama um maior conhecimento da essência do homem e de seus propósitos frente à problemática da existência. Aprendemos que todas as cogitações sobre os temas de Direito, são, antes de mais nada especulações em torno de comportamentos individuais orientados pelas normas jurídicas. O Direito, em qualquer de seus ramos, não é fenômeno de flutuação sobre a realidade, mas se constitui na ciência cultural que consulta e procura aiender as solicitações comuns na sociedade organizada, na medida em que suas normas mantém um sistema de valorações e finalidades o qual se mostra vinculado na história ao vasto conjunto de idéias e pensamentos fundamentais, como expressão de desenvolvimento teórico e prático de um povo.

Mas a norma jurídica, como instrumento intelectivo de manifestar o dever ser, não se propõe a identificar o homem como entidade natural. Seu objetivo final é uma relação e sua gênese está numa valoração.

Quando a norma exige determinada conduta sob cominação de uma sanção específica, não está procurando ana!isar o homem, mas estabelecendo um juízo de relação valorativa entre o comportamento, como expressão do ser e a conduta exigível como forma do dever ser.

Tivestes, durante o tempo dedicado à Universidade, condições para um meticuloso exame de diversas leis, de vários sistemas para interpretá-las; tivestes a visão clarificada de inúmeros doutrinas elaboradas e desenvolvidas para permitir o processo de inieligência das normas jurídicas, de maneira a conduzi-los através de uma jurisprudência conceitualista.

Mas, porque o Direito não pode ser compreendido em função de um logicismo abstrato de uma perspectiva alienante da realidade, na evolução do curso jurídico, recebestes também a noção de que as normas de Direito se propõem a resolver um conflito de interesses, no qual o juiz exerce sua função no sentido de reconhecer, entre os interesses em colisão, qual deva merecer prevalência. Esse seria o 
método chamado jurisprudência de interesses e que surgiu historicamenie no campo do Direito das obrigações, onde a posição respectiva do devedor e do credor provocou o aparecimento da idéia.

Porém, se de um lado não é possível abstrair o método lógico porque imprime dignidade de expressão ao Direiro, também não se pode negar que em diversos momentos da vida o homem é um ser utilitarista, agindo em função de conveniências próximas ou remotas, razão pela qual o ordenamento jurídico adquire fisionomia pragmática, na tutela de certos interesses individuais ou coletivos.

Essas correntes de método estão vinculadas à própria historicidade do Direito, posto que representam tendências extremadas na consideração do fenômeno jurídico e foram responsáveis pela deforma. ção de diversas instituições, emprestando-lhes caracteres impróprios à sua natureza e ao seu destino.

Enquanto nos períodos inquisitoriais os conceitos sobre o bem e o mal eram construídos metafisicamente, servindo ○ Direito tão somente como reflexo de força favorável aos deuses preferidos, já nos regimes tolalitários e agnósticos, como os emergentes das grandes guerras, as doutrinas sobre o justo e o injusto eram forjadas em atenção aos interesses do poder político dominante, convertendo-se - Direito em instrumento de coerção de idéias ou em meio para satisfazer as pretensões dos déspotas, temporariamente investidos num comando.

Sois uma parcela representativa da mocidade brasileira, cujo mérito maior reside na desvinculação das tendências meramente conceitualistas ou simplesmente utilitárias.

Estou me dirigindo aos moços que durante os anos de fraternal convívio universitário, sempre revelaram por idéias e atitudes, a ausência de compromissos prévios com a lógica abstrata ou a teoria dos interesses pragmáticos para mensurar o homem e analisar o mundo.

Tenho certeza, na medida em que vos conheci, que sois suficientemente livres para vos orientar na vida em função de uma jurisprudência dos valores considerando-se como valor a nafureza das coisas e expressas em termos intelegíveis para que o homem possa dele servir-se para seus fins morais.

Em torno dos valores do homem e da própria natureza, movimenta-se o Direito na sua função de tutela. As instituições jurídicas que preservam a vida, a liberdade, a honra, o patrimônio e os demais bens necessários à conservação finalística da sociedade, estão embasadas de valores que penetram e iluminam a realidade. 
Na qualidade de juízes, ireis decidir não um mero conflito de interesses reversível em dinheiro, mas ireis julgar com qual dos litigantes está a boa razão, valorizando a pretensão jusia. Lembrai-vos sempre que as vicissitudes instrumentais do ordenamento judiciário são responsáveis, em grande parte, pela demorada prestação da justiça em detrimento dos economicamente fracos.

Muitas vezes ireis sentir que a importância da judicatura não está no cargo em si mesmo, mas na condição humana de quem o exerce. $O$ juiz moderno, além das qualificações de inteligência e cultura, deve projetar a sensibilidade de modo a envolver não somente as pessoas e coisas que recaem no seu campo de julgamento, como também as demais entidades e valores da sociedade, desenvolvendo, assim, um fecundo e constante processo de comunicação. Não creio em boa administração da justiça com o desconhecimento do homem e de outros valores distribuídos em sua circunstância, posto que o Direito é ciência de valores sociais e a finalidade da Justiça é o reconhecimento do Direito.

Ao lado da magistratura e também visando o bem comum, está - Ministério Público, que, através de seus agentes, promove a nobilitante tarefa de pugnar pelo cumprimento das leis.

Não existe entre juízes e promotores no desempenho de suas funções, diferenças qualitativas e nem superposição de hierarquia, pois tanto um como outro, nos limites de suas atribuições, realizam a obra comum de preservar os valores que emprestam relevo à vida.

No exame das causas que envolvem bens jurídicos fundamentais à coletividade organizada, juizes e agentes do Ministério Público desempenham igual sacerdócio na essência, ainda que diversificado

Mas, a realização dos objetivos mais altos no campo da técnica do Direito deve ser valorizada pela conduta como ser social. Antes de juízes e promotores, deveis ser pessoas humanas sobre as quaïs incide um julgamento social, devendo, portanto, vos conduzir de modo a receber a admiração dos concidadãos, não somente pelas sentenças justas e pelas iniciativas diligentes no curso dos procedimentos, mas, igualmente, pelo caráter, pela personalidade, pelo sentido de responsabilidade que deve orientar vossos rumos pessoais.

Além de tais virtudes, é preciso também a qualidade para compreender o Direito em sua tessitura dinâmica, como um processo que vai adquirindo nova fisionomia a partir dos momentos que marcam os novos estágios de evolução social.

Paralelamente aos juízes e agentes do Ministério Público, na defesa dos interesses que lhes são confiados, está o advogado. 
A profissão da advocacia nos dias atuais constitui um munus público, abandonada a concepção que a considerava como atividade privada de caráter liberal.

A propósito, o Estatuto da Ordem dos Advogados do Brasil (Lei n. ${ }^{\circ} 4.215$ de 27 deabril de 1963) estabelece que no seu ministério privado o advogado presta serviço público, constituindo com os juízes e membros do Ministério Público, elemento indispensável à administração da justiça.

O principal dever dos advogados é o de defender a ordem jurídica e a Constituição da República, pugnar pela boa aplicação das leis e rápida administração da justiça, além de contribuir para - aperfeiçoamento das instituições jurídicas.

Projeta-se o exercício da advocacia num plano que transcende as relações entre o profissional e seu cliente, para ganhar um słatus de dignidade, uma vez observados os deveres e direitos que defluem da referida Lei e dos preceitos da ética profissional.

Proclamando a independência profissional, a Lei dispõe que entre os juízes de qualquer instância e os advogados não há hierarquia, nem subordinação, devendo-se todos consideração e respeito recíprocos, muito embora deva o advogado velar pela dignidade da magistratura, tratando as autoridades e funcionários com respeito e altivez, não prescindindo de igual tratamento.

Para exercer a profissão com liberdade, deve o advogado representar ao poder competente contra autoridade e funcionários por falta de exação no cumprimento do dever; preservar, em nome da liberdade de defesa e do sigilo profissional, a inviabilidade de seu domícílio, de seu escritório e arquivos; comunicar-se, pessoal e reservadamente, com seus clientes ainda quando presos em estabelecimento civil ou militar, mesmo incomunicáveis; recusar o patrocínio de causa que considere imoral ou ilícita, salvo a defesa em processo criminal.

O complexo dos direitos e deveres que regula o comportamento do advogado, não mais decorre de concepções românticas oriundas do lluminismo ou das idéias pragmáticas de uma civilização materialista que via no advogado um simples procurador agindo como delegado na defesa de direitos alheios.

$\mathrm{Na}$ atualidade e particularmente em nosso país, os famosos Decálogos foram substituídos por um conjunto de textos legais que im primem dignidade e vigor à profissão. Sem qualquer dúvida, essa evolução não é consequência de uma visão conceitualista ou de uma 
jurisprudência de interesses, mas está vinculada num sistema de valoração de atividade.

Dentro dessa moderna concepção, que vê a figura do advogado sobre critérios de valor, ele é considerado um ser socialmente solidário, quando, entre os deveres legais, está obrigado a prestar, gratuitamente, serviços profissionais aos necessitados quando nomeado pela Assistência Judiciária, pela Ordem ou pelo Juízo.

A maior expressão de reconhecimento cultural do ministério da advocacia repousa na disposição do Estatuto que, proibindo, in these, advogar contra literal disposição de lei, presume a boa-fé e o direito de fazê-lo, com fundamento na inconstitucionalidade ou na injustiça da lei. Tem, assim, o advogado, em razão da tese que sustenta numa causa, possibilidade efetiva de contribuir para a modificação ou revogação de textos viciados.

Essa liberdade intelectual, de refundir o próprio Direito positivo, confere dimensões de alta nobreza ao comportamento profissional, além de render homenagem àqueles que tratam dos casos particulares com o zelo e a inteligência que também servem ao interesse público.

A liberdade profissional assume diversos matizes e seu momento culminante reside na declaração formal do Estatuto quando reza: nenhum receio de desagradar o juiz ou qualquer autoridade, nem de incorrer em impopularidade, deterá o advogado no cumprimento de sua tarefa e deveres.

Em norma de de garantia social e política imuniza a ação do profissional contra qualquer forma de agressão preconceituosa, venha de onde vier, de qualquer cor ou credo.

Conta BERRIER em suas recordações que por ocasião do julgamento de LUIZ XVI, combinaram alguns advogados, decididos a assumir a perigosa responsabilidade da defesa, que o escolhido pelo Rei iniciasse o discurso com esta declaração: "Trago à Convenção a verdade e minha cabeça. Poderá ela dispor de uma, após ouvir a outra".

Comentando esse episódio, ponderava HENRI ROBERT, que tanto enalteceu a profissão: "A justiça de gorro vermelho aceitava mais facilmente a cabeça do que a verdade".

Posso vos afirmar, com experiência pessoal, que quadros históricos dessa natureza não se ajustam à realidade brasileira, posto que a nossa legislação é provida de dispositivos que permitem ao advogado intervenção sumáría durante os julgamentos, como também ga- 
rante a palavra perante qualquer juiz ou tribunal para replicar acusação ou censura que lhe sejam feitas, durante ou por motivo do julgamento.

Vistes, meus estimados Colegas, que as profissões do Direito são revestidas de elevação e dotadas de sentido finalístico.

Cada um de vós, enfrentando os problemas do cotidiano com uma parcela diária de heroismo, poderá realizar o bem comum.

Quanto ao bem pessoal, ao estado singular de satisfação, posso vos afirmar que a vida profissional não se compõe de regras pré-fixadas ou de um programa monótono de existência que tanto mediocrizam o homem e estrangulam o seu poder de criação, mas é plena de momentos que dinamizam o espírito, ora através de lances dramáticos, ora em passagens de alegria, permitindo-lhes, como analistas sensíveis nos casos concretos, um comportamento superior que se superpõe às dores do mundo, ainda que vossos caminhos encontrem o ódio, a inveja, a traição e toda a corte de forças do mal.

Daqui há algum tempo, quando houver uma integração efetiva na profissão do Direito, podeis dizer como o poeta:

"Lancei minh'alma ao espaço

a procura de um bem sempiterno

e quando ela a mim tornou

trouxe um pouco de céu e um pouco de inferno".

Assim direis, não como expressão de amargura, de tédio ou de renúncia, mas como afirmação de vigor íntimo, como um hino de amor à vida, aos homens e às coisas. Direis em estado de graça porque aprendestes a recolher de vossas experiências pessoais, todas as lições para formar uma vivência humanista.

Não tenho conselhos particulares para vos transmitir. Não farei pregações, nem entoarei cânticos, pois todos sois livres para amar, para sentir e para a eleição dos próprios caminhos.

Não posso exigir que todos tenham, desde logo, uma definição de carreira posto que são inúmeras as atividades ligadas ao Direito e que oferecem oportunidades no campo da comunicação social.

Muitos caminhos conduzem à Casa do Senhor.

Quero encontrar, amanhã ou depois, perto ou longe, juízes membros do Ministério Público, Advogados, Professores, Jornalistas, Políticos, não importa a qualificação profissional. Quero encontrar em vós, criaturas inifegradas em si mesmas e frente às circunstâncias que habitam. 
Lembro SAINT EXXPÉRY: "O que interessa perguntar a todo "homem não é qual a doutrina que professa, qual a sua marca, qual "o partido a que se filiou. O importante é saber que que espécie de "homem é ele. Que homem e não que indivíduo. O que interessa é o "homem integrado num grupo, num país, numa civilização. Os fran"ceses escreveram nos frontões de seus monumentos: liberdade, igual"dade, fraternidade". Tinham razão, é uma bela divisa. Desde que, acrescenta SAINT ÉXUPÉRY, se compreenda que os homens não podem ser livres, iguais e irmãos "a não ser em alguém ou em alguma coisa".

Este é, no meu entender, um aspecto fundamental da liberdade. Liberdade para julgar conceitos, liberdade para a escolha de caminhos conforme as rendências particulares e o sentido que se empresta à vida.

Para essa liberdade, estou certo, contribuirá a vossa formação no curso de Direito.

E assim estamos pagos: os professores porque durante o tempo de ensinança colaboraram na formação de perfis universalistas e os vossos pais porque fizeram nascer e crescer pessoas capazes e humanistas.

Quero terminar. Não tive meios de expressar pessoalmente, como pretendia, o agradecimento pela honra que me deferistes.

Desejaria estar convosco muitas vezes para tentar retribuir a homenagem que tanto me sensibiliza e concede à minha vida no magistério uma graça interior.

Neste momento, nesta solenidade tão importante para todos nós, diante de vossos pais, próximos e distantes e dos demais parentes que vos amam, eu manifesto a minha imorredoura gratidão.

E continuarei devedor pelo vosso gesto de amizade e ternura, se na distância dos anos e dos caminhos onde estivermos, eu seja lembrado, assim como fui; assim como sou. PÉRY:

Que eu seja lembrado à maneira do Pequeno Príncipe de ÉXU-

"Terei o aspecto de estar morto e isso não será verdade. E quando te consolares (a gente sempre se consola), ficarás contente por teres me conhecido.

Serás sempre meu amigo. Estamos contentes de o ter conhecido; seremos sempre seus amigos" 